Title:

\title{
Religion, Civilisation, geography: Normative EU Studies and Eastern Enlargement
}

\begin{abstract}
Taking scholarship on the EU's 2004 eastern enlargement as a case study, this article asks whether EU studies (EUS) scholars make normative judgements about how far east the EU should expand and whether these judgements involve civilizational thinking. Civilisations are categories devised by scholars to classify peoples into coherent ancient, continental-scale cultural groups, largely defined by shared history and religious tradition. They matter for their supposed political and historical significance. This article finds that normative civilisational references to eastern enlargement are quite common in EUS texts but usually marginal. They are implied for example in the terms Europe, West and East or in throwaway remarks in the introductions of scholarly articles. Constructivist scholarship deconstructs normative language in two competing civilisational narratives, associated with the progressive West and traditional Christian Europe which probably helped persuade Western European leaders to enlarge the EU to the east and are severely damaging Turkey's candidacy. EUS scholars also apply a historical sociology approach to culture. They suggest that historical legacies which are deeply embedded in the social structures and practices of specific groups of people over the longue durée create the social and economic conditions that determine suitability for EU membership.
\end{abstract}

Keywords

EU enlargement, EU studies, civilisation, European identity, normativity 


\section{Religion, civilisation, geography: Normative EU Studies and eastern enlargement}

Taking scholarship on the EU's 2004 eastern enlargement as a case study, this article asks whether EU studies (EUS) scholars make normative judgements about how far east the EU should expand and whether these judgements involve civilizational thinking. Like language families and anthropological races, civilisations are categories devised by scholars ${ }^{1}$ to classify peoples into coherent ancient, continental-scale cultural groups with supposed significance for political and historical development. Scholars use physical geography and elements of shared history to define civilisations, but their key criterion is religious tradition (Katzenstein 2010, 4).

The EU has been slow and picky in accepting ex-communist countries as members, so far admitting just eleven of the 22 that have declared an aspiration to join (Lavenex 2004, 682). In December 2001, the European Council selected the first batch of eight, which joined in May 2004. Certain EUS scholars identify a cultural element in this selection (Schimmelfennig 2003, 180; Risse 2009, 156-57). Helene Sjursen for example sees religion-based cultural identity narratives as crucial to the geography of eastward enlargement (2002, 502-4). She says intellectuals like Milan Kundera, Vaclav Havel and Adam Michnik in ex-communist countries with a 'Western' Christian (Catholic and Protestant) tradition successfully traded on ancient civilisational kin-responsibility to persuade the EU and Nato to let them join. They portrayed Central Europe as returning to complete the West after being 'kidnapped' by a culturally alien Russia (Kundera, 1983; Judt 1992, 92). The 2004 eastern border of the EU, which is perpetuated by that of the current Schengen border-free zone, appears to support this civilizational explanation. It coincides remarkably well with the eastern extent of Western religious tradition.

For at least three reasons however, EUS avoids analyses that explicitly treat civilisations as important. First, they have unsavoury associations with right-wing identity politics because their ancientness make them appear fixed, essential and intractable. Russia's civilisational split with the West can for example be traced to the Western-Orthodox religious schism of $1054 \mathrm{CE}$ or even the division of the Roman Empire in 285 CE.

Second, EU decision-making and social science share a bias towards rationalist rather than cultural explanations. The EU ostensibly based its enlargement decision on dispassionate rational assessment of current political, institutional, legal and economic compatibility with existing members. Lykke Friis and Anna Murphy describe EU member states' only cultural concern regarding enlargement as wanting to avoid accusations of 'redrawing the old cultural boundary of Western Christendom' (1999, 225). Other EUS scholars identify a more selfish rational calculus among member states, prioritising their own economic, security or geopolitical costs and benefits over 'moral' motives such as democracy promotion (Moravcsik and Vachudova 2005, 198-99; Grabbe and Hughes 1998, 5-6).

Third, specific histories and geographies are central to the civilisational concept of culture as the ancient and unchanging heritage of specific bounded societies (Katzenstein 2010,3). However political science, the core discipline of EUS (Rosamond, 2007, 10), rarely takes interest in these. It prefers developing generalisable theories, which are applicable in any

\footnotetext{
${ }^{1}$ Since the early twentieth century a loose, interdisciplinary collection of western European and American scholars have studied civilisations. Following Oswald Spengler in 1918 (1979), works by Arnold Toynbee, Pitirim Sorokin, Alfred Kroeber and others in the late 1930s and 1940s marked the school's highpoint, followed by a revival in the 1960s by Fernand Braudel and William MacNeill (Sanderson 1995: 15).
} 
context. The core corpus of enlargement research is thus concerned with 'definitions, research focuses, and hypotheses [that] can be applied to the enlargement of other regional organizations and are designed to encourage comparative analysis' (Schimmelfennig and Sedelmeier 2002, 502-3). The right-hand column of table 1 below makes this clear. The vast majority focus heavily on theoretical debates rather than the detail of which countries should or should not join the EU. Despite the centrality of geography to Sandra Lavenex's article on the concentric circles of EU external governance for example, none of the six key questions for further research that she proposes examine the specifics of this geography (Lavenex 2011, 389-90). An important body of research by EUS scholars such as Frank Schimmelfennig ascribes a key role to cultural narratives in persuading EU decision-makers to accept enlargement. However even here, the focus is on non-geographically specific questions of whether and how, in general, these narratives were instrumentalised. Only a third of the nine articles in the table that refer to culture or religion therefore link this with the accession prospects of specific countries.

\begin{tabular}{|c|c|c|c|c|c|}
\hline Citations & Author(s) & Year & $\begin{array}{l}\text { Author } \\
\text { discipline }\end{array}$ & References to civilisation, culture, religion & $\begin{array}{l}\text { Focus on theory or which } \\
\text { countries qualify for EU } \\
\text { membership }\end{array}$ \\
\hline 1101 & Schimmelfennig & 2001 & Political science & culture & theory \\
\hline 939 & Baldwin et al. & 1997 & Economics & no & theory \\
\hline 829 & $\begin{array}{l}\text { Schimmelfennig } \\
\& \text { Sedelmeier }\end{array}$ & 2004 & Political science & no & theory \\
\hline 478 & Lavenex & 2004 & Political science & no & theory \\
\hline 409 & $\begin{array}{l}\text { Kopecký \& } \\
\text { Mudde }\end{array}$ & 2002 & Political science & religious stance of some Eurosceptic parties & largely theory \\
\hline 400 & $\begin{array}{l}\text { Schimmelfennig } \\
\text { et al. }\end{array}$ & 2003 & Political science & no & theory \\
\hline 371 & $\begin{array}{l}\text { Moravcsik \& } \\
\text { Vachudova }\end{array}$ & 2002 & Political science & no & theory \\
\hline 341 & Marks et al. & 2006 & Political science & religious stance of Tan parties & east vs. west (also theory) \\
\hline 335 & Smith & 2005 & Political science & $\begin{array}{l}\text { fear of Islamism weakens EU democracy } \\
\text { promotion }\end{array}$ & theory \\
\hline 252 & Friis \& Murphy & 1999 & Political science & religion in Turkey's perception & theory \\
\hline 218 & $\begin{array}{l}\text { Taggart \& } \\
\text { Szczerbiak }\end{array}$ & 2004 & Political science & no & theory \\
\hline 169 & $\begin{array}{l}\text { Fuchs \& } \\
\text { Klingemann }\end{array}$ & 2002 & Political science & culture, civilisation and religion central & countries \& theory \\
\hline 168 & $\begin{array}{l}\text { Christiansen et } \\
\text { al. }\end{array}$ & 2000 & Political science & $\begin{array}{l}\text { civilisation: Russia vs W. Europe; Islam as } \\
\text { proposed common identity in south Med; } \\
\text { Euro-Med to escape focus on 'Islamic threat' }\end{array}$ & countries \& theory \\
\hline 160 & Cichowski & 2000 & Political science & no & theory \\
\hline 143 & Zielonka & 2001 & Political science & culture & $\begin{array}{l}\text { theory but can } \\
\text { enlargement differences } \\
\text { be overcome }\end{array}$ \\
\hline 137 & Baldwin & 1995 & Economics & no & theory \\
\hline 109 & Schimmelfennig & 2003 & Political science & culture & theory \\
\hline 107 & Agnew & 2001 & Geography & no & $\begin{array}{l}\text { countries (based on } \\
\text { economics) }\end{array}$ \\
\hline
\end{tabular}

Table 1. The 18 articles on EU enlargement and EU policy towards neighbouring countries that were cited over 100 times (Google Scholar², 29/4/2015).

\footnotetext{
${ }^{2}$ Despite several important flaws, including a strong Anglophone bias, Google Scholar is the best available
} 
A few EUS scholars, like Sjursen, examined statements by EU officials to assess how cultural narratives represented specific groups of countries as suitable EU membership candidates. However the present article is the first to investigate the language of EUS scholars about these normative geographies. As one of the few genuinely transnational fora where Europe can discuss integration with itself, EUS constitutes an important informal institution of European integration. As a transnational European elite with a largely rationalist ethos, EUS can also serve as a useful research proxy for the thinking of EU officials and political leaders. Mid1990s EUS literature for example often accurately predicted the geography of the EU's 2004 enlargement because it and the European Commission used the same rational evaluations of factors like democratisation and economic development (Rose and Haerpfer 1995, 443; Kramer 1993, 218-19; Baldwin 1995, 475). However EUS writings are more voluminous and detailed, and discuss culture with deeper reflexivity. A further advantage of analysing scholarship is that the most authoritative work can be identified using citation indices.

Because of its rationalist social scientific ethos, EUS scholarship rarely recognises its own normativity. This article therefore first assesses normativity in EUS writing on eastern enlargement. It finds normative civilisational geographies are quite common, but usually marginal. I then examine two EUS approaches to culture. First, constructivists identify the powerful impact on the enlargement process of two rival civilisational narratives, associated with the progressive West and traditional Europe. Second, EUS engages in complex and sometimes unconscious ways with historical sociology.

\section{Rationalism and normativity}

The highpoint of explicitly normative and civilisational scholarly debate on European geography accompanied the collapse of communism in the late 1980s and early 1990s. The dissolution of Europe's 'relatively stable' Cold War territorial framework forced western Europeans to consider how far the EU could or should expand to the east. This context also stimulated Samuel Huntington to resuscitate the civilisation concept as an identity marker (1993), helping to script the West's geopolitical confrontations with Islam and Russia. Huntington claimed Western Europeans 'overwhelmingly support sotto voce, and... intellectuals and political leaders have explicitly endorsed' a civilisationally Western Europe, leaving out Russia and the Balkans $(1998,158)$.

citation database (Harzing \& van der Wal, 2008: 63-65). 


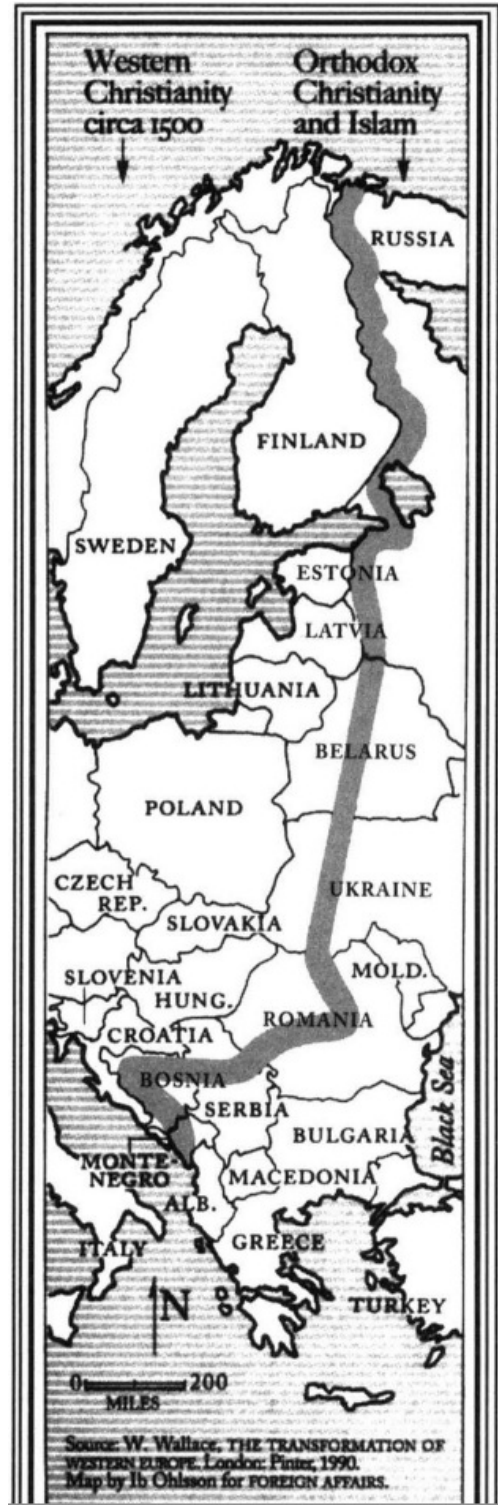

(1998, 159).
The civilisational map (see fig. 1) that his controversial Clash of Civilisations borrowed from William Wallace, a leading Oxford EUS political scientist and active pro-European politician, became notorious in eastern European debates about accession to Western institutions. Wallace discussed EC enlargement in intensely normative civilizational language. There were 'immense dangers' in defining 'Europe' as Christian' but 'good historical justification' for it (Wallace 1992, 40-41). Greece and Turkey were 'arguably outside the framework of 'Western' values, shared history and culture, which gave the Community a sense of community'. Wallace offered a hierarchy of likely accession candidates, from Catholic Central Europe 'with established claims to be 'rejoining the West', to the Balkans, 'historically less closely associated' and Turkey, 'like Russia, a Euro-Asian country in geography, history and culture’ (1992, 42).

The historian Timothy Garton Ash agreed. In a 1991 article entitled 'Let the East Europeans In!', he trumpeted that it 'makes plain, practical sense' to begin enlargement with Poland, Hungary, and Czechoslovakia, the 'nearest' countries 'geographically, historically, and culturally' as well as in progress towards 'democracy, the rule of law, and a market economy'; they 'belong to Europe' and excluding them was 'historical nonsense' (cited in Neumann 1999, 156). In 1992, the historian of nationalism Anthony Smith called the Orthodox-Western split the 'most potent' divide among Christians, and asked whether if 'religion is a real criterion of identity, should not Poland, rather than Greece, be a member of the new Europe?' (1992, 69).

Fig 1. Huntington’s 'eastern border of western civilisation’

Another prominent historian, Tony Judt, argued against this powerful civilisational narrative distinguishing culturally 'Western' Central Europe from the Orthodox east. He instead advanced cultural arguments for a narrower Western Europe. This supported traditional Eurofederalist advocacy of 'swift political union, based firmly in the Western heartlands' (Smith 1992, 67). Judt wrote that longstanding 'cultural and commercial links' gave western Europe 'a common and distinctive history' $(1996,50)$. East of the Trieste-Gdansk line that bordered Charlemagne's empire, the Hapsburgs' Austrian lands and the Soviet bloc, he placed 'a no less distinctive if less fortunate eastern Europe' $(1996,51)$. This included the small, provincial, 'overwhelmingly Catholic, rural', illiberal, squabbling nations of central Europe (1996, 52, 57 \& 68).

Historians of contemporary Europe such as Garton Ash, Smith and Judt dominated the highprofile immediate post-Cold War debate about EU enlargement, while EUS political scientists like Wallace were less prominent. Different disciplinary approaches to normativity may help explain this. My quantitative analysis of normative language in the most cited EUS political science articles found a sharp decline in levels of normativity in top-cited political science EUS 
articles during the mid-1990s ([anonymised] $2017 b^{3}$ ). They increasingly avoided overt political advocacy and favoured the emotionless, impersonal style of social science over strongly positive or negative language. Most importantly, they were increasingly careful to base assertions, including about countries' qualifications for EU membership, directly on evidence such as statistical analyses, detailed argument or citations of practitioners or scholars.

Already in 1993 for example, in an article a year before Wallace's and on precisely the same subjects, the prominent German EUS political scientist Wolfgang Wessels limited himself to reporting the policy-makers' hierarchy of likely accession countries, rather than proposing his own ranking (1993, 308-9 \& 313-14). The $17^{\text {th }}$ most cited enlargement article (see table 1) used Freedom House and Polity data to argue that in 1998-2000, the EU began membership talks with 'the most democratic' CEE countries (Schimmelfennig 2003, 179). The $16^{\text {th }}$ most-cited based its enthusiasm about the 'potentially enormous' gains of enlargement on detailed economic analysis (Baldwin 1995, 475). Other scholars pointed to 'nationalist and traditionalist movements' in Balkan and former Soviet states, as evidence that optimism was 'more justified' about the 'vastly' more economically and politically developed and democratic countries of Central Europe (Rose and Haerpfer 1995, 443; Kramer 1993, 218-19; Wallace 2005, 291). Calls for a small Europe could be understood in terms of rational interests like preserving the Western European social model and keeping Polish plumbers out of labour markets.

As table 1 suggests, EUS in any case concentrated on two theoretical questions, rather than the relative preparedness of specific candidates. A key early research question was the existing EU's willingness to accept enlargement, despite a distinct lack of enthusiasm among most member states and citizens (Grabbe and Sedelmeier 2010, 378; Moravcsik and Vachudova 2005, 203-4; Schimmelfennig and Sedelmeier 2002, 519). Then, in the 2000s, as CEE accession loomed closer, attention turned to enlargement's effects on the EU, and especially on whether it would undermine European governance and identity, paralyse Brussels decisionmaking or block further integration (Schimmelfennig and Sedelmeier 2002, 507; Friis and Murphy 1999, 212-13). Michael Gehler, a prominent Austrian historian of integration, for example worried that enlargement would 'water down' the EU, nullifying its 'ambitions as a world power' (2006, 282).

However scholarship does not float above society in an apolitical aether. Historians of science and sociologists of knowledge generally assume social and political influences (Berling and Bueger 2003, 115). The personal background of scholars, competition for funding, academic institutionalisation, transnational organisation, disciplinary traditions, popularisation efforts and the interface between academia and policy-making can all encourage politicised narratives. These can be expressed in the presentation of results and choices of research topic, evidence, methodology and theoretical framework.

The professionalisation of EUS may now have made boundaries between political engagement and academic research firmer and normative work less acceptable. However, career and funding incentives increasingly encourage EUS scholars, like other scholars, to maximise their impact outside academia. UACES, the principle British professional society for ES/EUS and leading academic EUS journals like Journal of Common Market Studies and Journal of European Public Policy (JEPP) still explicitly aim to engage with political actors and link academics with them (Popa, 2007, 127, 132 \& 138-39). A key funding source for the

\footnotetext{
${ }^{3}$ I attribute this to increasing professionalisation of political science. This stimulated intensified demarcation from other disciplines, such as history, especially through a radically rationalist 'scientific' and ostentatiously objective style of research.
} 
development of EUS, the European Commission's Jean Monnet Programme, has the explicit political goal of promoting civil society engagement with European integration (Belot and Brachet, 2004, 149-51; Georgakakis and Smith, 2004, 9).

The historian Mark Gilbert therefore argues that both historians and political theorists of European integration have 'coincidentally' but systematically generated normative 'narrative accounts' (Gilbert 2008, 649). My own research (2017a) bears this out. I found that if scientific work had the potential to support political arguments, at least some of it usually did, often in the form of politicised narratives in implicit subtexts and throwaway remarks. I found evidence of normativity in almost $85 \%$ of the 73 most cited political science EUS articles.

Normativity was however usually expressed in marginal ways, rather than as a central concern. Assertions that were not closely supported by immediate evidence often for example appeared as bold, scene-setting general statements in the introductions of articles, or in conclusions, where authors synthesised their arguments and drew broad implications from them. The introduction of a 1999 article by the former deputy president of Poland's EU studies association, the economist Renata Stawarska, thus blatantly lobbied for Poland's accession, noting that its WWII exile leaders 'established their credentials' as 'among the founding fathers of a united Europe' $(1999,823)$. This normativity is by no means confined to accession country scholars. JEPP was content to publish Stawarska's article, despite its politicised appeals. Richard Rose of Strathclyde University and Christian Haerpfer of Vienna meanwhile began their analysis of survey statistics by stating that before 1945, 'Prague, Budapest and Warsaw were as much European cities as Rome, Madrid and Lisbon' (1995, 428). The second most cited article in table 1 unequivocally supported enlargement, calling it 'a simple way simultaneously to ensure the bright-side economic outcome and to alleviate' Europe's 'power vacuum’ (Baldwin, Francois, and Portes 1997, 128).

Top-cited articles preferred to explain the geography of enlargement using relatively uncontroversial cultural ideas like 'history' and 'norms', which were connected with concrete experience, rather than 'culture' or, especially, 'civilisation', which referenced vague and essentialised identities. Religious references were rarer still, used explicitly to explain enlargement geography in just one of the most cited articles (Fuchs \& Klingemann 2002). The single most cited article on enlargement nevertheless characterised Hungary, Romania and Georgia's claim to 'have traditionally shared the values and norms of European culture and civilization’ as ‘improbable’ (Schimmelfennig 2001, 68-69). The eighth most cited article said enlargement spread 'the defining ideals of Western civilization' (Marks et al. 2006, 155).

A second expression of normativity derived from the limited reflexivity of political scientists regarding the implied associations of terms such as Europe, East or West. Frequent talk of uniting, reuniting or 'stitching together' Europe, whose division made 'a mockery of the very term "European Union”, apparently essentialised Europe as a self-evident ancient unit (Smith 2005, 757; Marks et al. 2006, 155). This may reveal subconscious civilisational thinking and an inattentiveness to civilisational language, which reflects the focus of political science research on present politics, rather than on culture or the past. Alternatively however, in the 1990s especially, some language referencing East-West dichotomies (whether or not using capital letters or inverted commas) might also reflect the mental geography habits of the Cold War (e.g. Baldwin et al. 1997, 128; Christiansen, Petito, and Tonra 2000, 396-97). Authors may merely have been advocating 'bridging the Cold-War divide' between former ideological blocs (Smith 2005, 757). 
Finally, as the following sections suggest, the two main two theoretical questions of EUS enlargement research can certainly be answered in cultural terms. The kidnapped West narrative offers an important reason for the EU's decision to enlarge and the diversity that made absorption difficult could also be represented as cultural.

\section{Enlargement and civilisation in EUS}

Civilisational analysis of enlargement in EUS engaged in quite different ways with two scholarly traditions that had contrasting ontologies of culture. Many EUS scholars have explicitly rallied behind a constructivist epistemological agenda since the 1990s. Other scholarship by contrast has an often undeclared resemblance to historical sociology.

\section{Constructivism: progressive West or traditional Europe}

After 2000, a 'surprisingly strong consensus' emerged in the enlargement literature that 'a rationalist, materialist framework' could not explain the EU's decision to enlarge ${ }^{4}$ (Schimmelfennig and Sedelmeier 2002, 521; Sedelmeier 2001, 14). Constructivism, which saw cultural appropriateness as an important factor in political decision-making, was then becoming increasingly influential in EUS, as it had become in IR. Whereas other scholarly approaches treated cultural distinctions between peoples as influential 'real world' factors, many constructivists saw and analysed them as creations of discourse, often serving political agendas. Thomas Christiansen, Fabio Petito and Ben Tonra for example question the 'historical authenticity and ... normative quality' of the 'frequent recourse to images of the Hanse' in the Baltic Sea region (2000, 394-95). The geographer John Agnew represented civilisation discourse as a mere justification for uneven economic development in Europe (2001, 35).

Constructivists argued convincingly that constructed European cultural norms heavily influenced the decision to enlarge. The dominant version of this argument held that Europeans, especially through engagement with dissidents in the Soviet satellite states, had developed a self-conception as champions of democracy, rule of law and human rights beyond their borders (Sedelmeier 2001, 16; Fierke and Wiener 2005, 108-9). Implicit promises made to encourage anti-Soviet dissidents shamed member states, despite their rational preferences, into accepting a civic duty to expand Europe's community of wealth and security.

Compared to Huntingtonian essentialism or historical sociology approaches, this general duty to the EU's troubled neighbourhoods, arising from intense theoretical engagement with normative philosophy, seems particularly unlikely to produce geographically specific normative narratives of enlargement. Karin Fierke and Antje Wiener for example insist that 'the ideal healthy state was a 'normative' category, rather than 'primarily... geographical or physical’ (2005, 107-8).

'Universal' rights are nevertheless very frequently (though not necessarily in constructionist literature) claimed as the specific heritage of a liberal, modern Western civilisation, associated with Enlightenment rationalism and civic nationalism. This civilisation discourse delimits Europe from eastern Europe. Christiansen, Petito and Tonra saw narratives of 'a 'Great Cultural Divide' between civilizations' as 'an important dimension' of 'European identity formation', constructing 'an Other' and supporting what they call the EU's 'imperial' policy in its eastern 'near abroad' (2000, 391-93). EU official discourse spoke of creating a politically stable 'ring of friends' beyond the immediate accession candidates, which would push back the 'zones of

\footnotetext{
${ }^{4}$ Andrew Moravcsik remains a prominent rationalist dissenter (Moravcsik \& Vachudova 2005: 198).
} 
turmoil... to the east and south' while not admitting these countries as members (Lavenex 2004, 689; Smith 2005, 757-61). Instead, association agreements were intended to harmonise their politics, economics and institutions with EU norms in order to project EU values of democracy, human rights and the rule of law (Lavenex 2004, 684 \& 688).

However EUS scholars also warn that rival EU, Russian and perhaps Turkish 'centres of gravity' may create competing and 'overlapping circles' of decreasing 'institutional density' in eastern Europe (Lavenex 2004, 695; Christiansen, Petito, and Tonra 2000, 392). Even when not explicitly civilisational, this recalls constructions of Western civilisation since the Enlightenment, including some in Russia itself, which often leave out Russia, the arch stalwart of conservative autocracy and chief Other of the Cold-War West (Mackinder 1904, 40; Wolff 1994, 10-11; Bassin and Aksenov 2006, 113). Heather Grabbe and Ulrich Sedelmeier predicted that 'the EU's normative agenda' would work against the future accession of Turkey, Serbia and formerly Soviet republics, as EU reluctance combines with candidate-state ambivalence, 'tied up with major questions about national identity' (2010, 387-89). For example, the EU's democracy and human rights agenda, which is central to constructions of European identity, controversially interacted with Turkish debates about secularism, freedom of expression and the rights of women and the Kurdish minority (Grabbe and Sedelmeier 2010, 392).

A narrower discursive geography of liberal Europeanness could even exclude Central Europe and the US. Ralf Dahrendorf warned in 1998 that because of 'deeper' cultural divisions separating 'East from West', rapid enlargement could dilute EU 'core values' like democracy, rule of law, 'cohesion and justice' (Laitin 2002, 75-76). Emanuel Adler called the narrow ColdWar Western Europe a new 'civilisational phase', in which 'Europe chose to reinvent itself' 'after European civilisation "crashed” in the first half of the twentieth century' (2010, 72-74). This not-quite-civilisational discourse defined (Western) Europe around values of social capitalism, human rights and 'post-modern' sovereignty-sharing. It rejected the rampant individualism of Anglo-Saxon Western neoliberalism and the 'modern' statism, militarism and nationalism of the US and its eastern European allies. Inverting Western Europe's post-modern historical progression, the former American Defence Secretary Donald Rumsfeld favourably contrasted these easterners with the 'Old Europe’ of Germany and France.

Helene Sjursen offered a second constructivist explanation for enlargement, highlighting the role of conservative narratives of 'kinship-based duty' to the ancient religious-based European cultural community (2006, 12-13). Twentieth-century historians like Henri Pirenne and Alfred Toynbee, who used the civilisation concept, traced this traditional 'Europe' from the medieval Rhineland core of Western Christendom. Early European federalists appealed to these common Rheinish roots and the symbolism of Charlemagne (Smith 1992, 74; Larat 2006, 51). Several scholars note echoes of medieval Christendom in the geography of the early EEC (Delanty 1995, 39; Therborn 1995, 188).

These conservative narratives of Christian Europe have long competed with representations of a liberal modern West, infusing east-west civilisational discourse with ideological tension (Zielonka 1998, 66; Smith 1992, 74). Before 1945, writers and political actors regularly opposed France’s ‘Western' modern ‘civilisation' to Germany’s ‘Eastern', spiritual, romantic 'Kultur' and ethnic nationalism (Weiss 2002, 266-77; Delanty 1995, 102; Katzenstein 2010, 10). The pre-1918 Hapsburg, Tsarist and Prussian regimes of the east invoked traditional 'Europe' or Mitteleuropa to resist the confident expansion of liberal, modern Westernism. Interwar Catholics and left-wingers therefore often used Europe and Occident as rival synonyms (Orluc 2000, 125). Conservative discourses of Europe excluded the US, the acme of 
liberal modernity and an important Other against which Europe defines itself, plus also at times its ally Britain (Diez 2004, 329-30). The European integration pioneer Richard CoudenhoveKalergi therefore excluded both Britain and Russia from his 1923 map of Pan-Europa. De Gaulle's 1960s call for a common European home from Brest to Vladivostok similarly excluded the Anglo-Saxon West. Current defenders of traditional nationalism and religion, who oppose the EU's liberal post-nationalism, are among Europe's greatest admirers of Vladimir Putin, the current cultural personification of Russian autocracy (Braghiroli and Makarychev 2016).

Presumably due in part to America's conservative cultural turn, political narratives of European civilisation now tend to focus on excluding an Islamic rather than a Western liberal Other. Recent controversies over Turkish accession and the campaign by the Papacy and several countries for a reference to Europe's Christian tradition in the European Constitution's preamble exploited and promoted the definition of Europe by 'cultural heritage and Christian tradition' (Orluc 2000, 130). Sjursen saw this as a key reason why the EU enlargement policy was much stricter towards Turkey than Poland (Sjursen 2002, 505). Since 1994, European Christian democratic leaders have worked to effectively block its EU accession talks, openly labelling Turks as outside Europe’s ‘Christian-occidental tradition’ (Diez 2004, 329; Grabbe and Sedelmeier 2010, 375-76). Thomas Risse thought that although liberal 'elite ideas of modern and enlightened Europe' drove 'Western European support for Eastern enlargement', this enlargement and especially Turkish accession and immigration, 'put antisecular and antimodern ideas' about Christianity 'back on the European agenda' (2010, 205).

\section{Historical sociology}

An alternative EUS approach to enlargement gives historical cultural legacies a very different ontological status. They do not merely exist, as constructivism can imply, 'exclusively in the minds of individuals', in their discourse or in 'intersubjective understandings' such as 'shared identity' (Adler 2010, 68). They are instead deeply embedded in the social structures and practices of specific groups of people over the longue durée. This makes the social and economic conditions that determine suitability for EU membership a 'cultural' historical legacy.

This historical sociology explanation of culture dates back at least to Max Weber's claim that early Protestant practices and worldviews inadvertently stimulated modern capitalism. Norbert Elias and Schmuel Eisenstadt explicitly analysed civilisations as historical legacies, and scholars like Peter Katzenstein and Emanuel Adler have recently applied this approach to European integration. Studies of enlargement can also draw on sociologists like Emanuel Wallerstein (1974, 399-404 \& 413) and Jenő Szücs (1985), who argued that the core-periphery relations of the modernisation process created bands of different social conditions from west to east across Europe.

The work of some EUS comparative politics scholars has been quite sociological in form and a few have recognised historical and cultural elements in enlargement. Schimmelfennig and Hanno Scholtz for example explicitly used 'Huntington's classification of civilisations' to grade how likely 'Western', 'Orthodox' and 'Muslim countries' were 'to democratise' (2010, $447 \& 454)$. They acknowledged that historical cultural legacies impacted both 'the EU's readiness to offer membership' and the success of membership (Schimmelfennig and Scholtz 2010, 444). The fifteenth most cited article on enlargement argued that 'local legal culture' affected how 'laws function' and that effective EU legislation should be compatible with ‘local 
habits, tradition, preferences and resources' (Zielonka 2001, 513). The twelfth most cited agreed that 'durable cultural traditions', derived from religion, imperial rule and 'level of socioeconomic modernity', strongly influenced EU and CEE political 'values and behaviours' (Fuchs and Klingemann 2002, 20 \& 27-28).

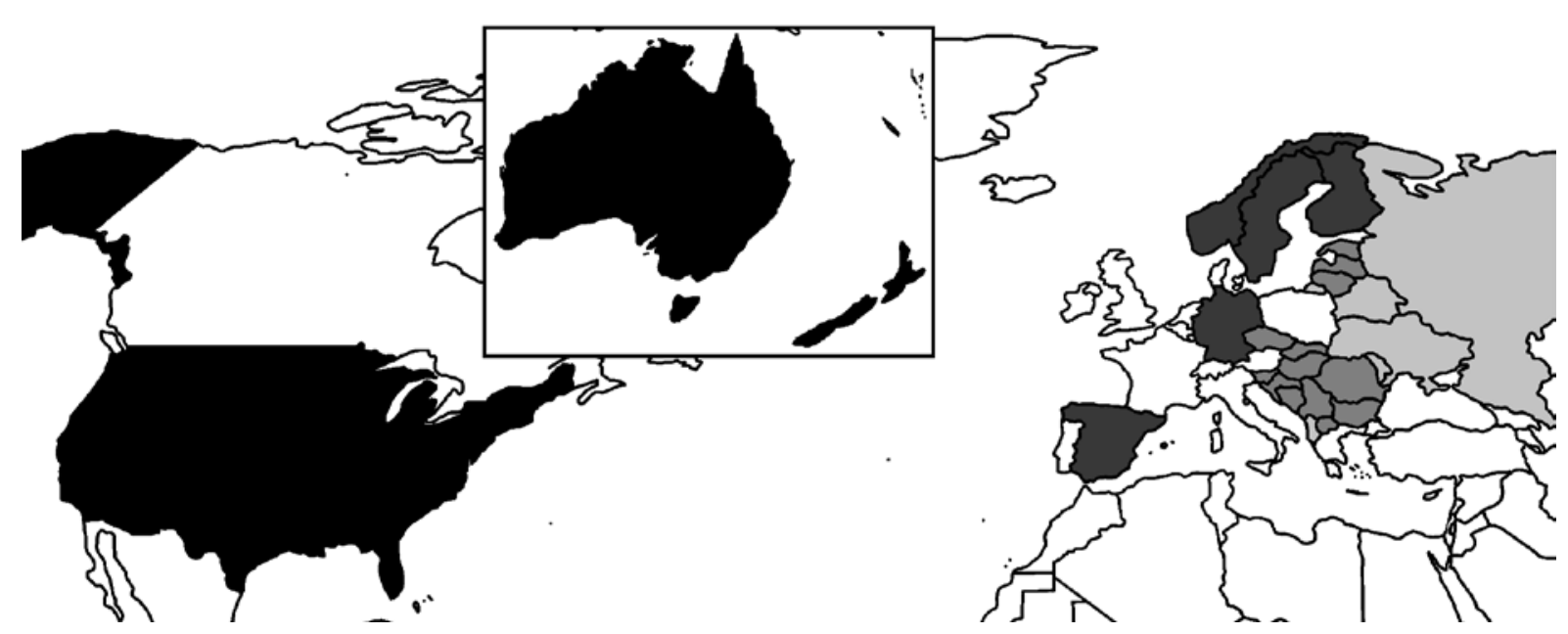

Fig. 2. Fuchs and Klingemann’s degrees of ‘democratic community’ (2002, 50).

EUS research on historical cultural legacies especially scrutinised democracy. An empirical study by Dieter Fuchs and Hans-Dieter Klingemann identified a 'continuous decline in... democratic community' from west to east (2002, 50 \& 52; see fig. 2). Schimmelfennig and Scholtz confirmed that in 1988-2000, a 'Western' Christian legacy was the best predictor of democracy among the EU's neighbours, followed by Orthodox Christianity' and, lastly, Islam, (2010, 444, 448 \& 454). Former rule by 'different colonial or multinational empires', length of 'independent statehood' and exposure to 'Soviet communist rule' had less clear effects (Schimmelfennig and Scholtz 2010, 447 \& 454-55). Katzenstein however argued that 'centuries of Ottoman rule' engendered 'autocracy... corruption' and 'enormous difficulties' in institutionalising Western legal practices, making Greek institutions 'singularly illequipped' to participate in European integration $(1996,145)$

The cultural diversity of accession countries became an important factor in the theoretical debate about enlargement's effect on the functioning of the EU. Many politicians and scholars feared it 'could significantly slow down or even halt' the national implementation of EU politics and policies, threatening the legitimacy of European governance as a whole (Falkner and Trieb 2008, 295). Heinz Kramer warned in 1993 that an EC of ' 25 economically and politically rather heterogeneous member States' could be 'totally unworkable' and incapable of further integration (1993, 239). Fuchs and Klingemann argued that Europe's east-west 'cultural gap' would inhibit a self-consciously European demos, undermining prospects for a 'viable European democracy' (2002, 19-20). Jan Zielonka agreed that 'in broader historical perspective', despite 'important common' characteristics, most candidate countries 'will long remain very different from the current members in terms of economics, democracy and culture' (2001, 508 \& 511). This would affect implementation of EU legislation and was 'bad news' for the federalist construction of 'a European super-state' (Zielonka 2001, 508 \& 529-30). He and others added however that the 'extremely complex' 'map of unity and diversity in the enlarged EU' did 'not simply correspond to the old East-West divide' (Zielonka and Mair 2003, 2). David Laitin thus provided evidence that the tastes in religion, language learning and pop 
culture of people in the CEE accession candidates resembled those in the original six EEC member states more than those of people in 1970s-1990s entrants did (2002, 61-63 \& 70-73).

History was rarely central to the research and training of EUS scholars and their very varied appeals to the past and culture reflected this. Some selectively chose isolated historical references, apparently for normative rhetorical effect. Richard Baldwin's political economy analysis noted that 'EU membership would symbolically restore' the 'Central European countries' 'to their historic positions among the advanced industrial economies of continental Europe' (1995, 480). Rose and Haerpfer favourably compared this region's 1990s transition to democracy to that of post-1945 Western Europe (1995, 428-29). Articlkes also however recognised that liberalism and civil society had 'no roots', in pre-communist central European 'political culture’ (Rose and Haerpfer 1995, 428-29; Judt 1992, 92).

The historical sociology approach could meanwhile be exploited to make narrative constructions of civilisational difference seem more plausible. The Hungarian politician and sociologist Kálmán Kulcsár therefore wrote that Soviet socialism, which 'in practice’, was 'connected with the Euro-Asian cultural sphere', created a barrier to the EU integration of eastern Europe by weakening the 'historical values and traditions' that created the 'base' of its European 'cultural and moral identity’ (1996, cited in Laitin 2002, 55).

As this suggests however, historical sociology recognised history as an ongoing process. Present and relatively recent developments, such as communism, interwar dictatorships and democracies, and European integration itself, all therefore shaped culture, which in turn influenced political factors such as participation in European integration. This challenged deterministic conservative understandings of civilisations as bodies of inescapable destiny, established once and for all by momentous ancient events such as Christianity's WesternOrthodox schism. Post-1945 Europe could therefore reinvent itself as Adler's 'civilisational community of practice', with new post-modern international relations practices $(2010,67)$. He believed this could overturn old civilisational geographies, expanding 'eastwards and southeastwards... offering membership or partnership' to 'societies which have experienced quite different routes to modernity' (Adler 2010, 77). Highly-cited EUS articles agreed that the EU's pre and post-accession policies could 'disseminate and consolidate the defining ideals of Western civilization - civil rights, markets, and democracy' (Marks et al. 2006, 155; Zielonka 2001, 511). The EU could help eastern Europe to overcome 'complex historical backgrounds', such as the communist 'laws, economy, education, ideology and culture', which were 'totally alien' to the West (Zielonka 2001, 511-13).

Although history continuously remade civilisations however, Katzenstein argued $(2010,15)$ that civilisational differences could survive as what Eisenstadt called 'multiple modernities'. Ancient factors like the different relationships between emperors and religious leaders in Orthodox and Western Christianity might reinforce and be reinforced by later socio-political factors within these civilisations (Katzenstein and Byrnes 2006, 686). Civilisations would therefore become modern while remaining culturally distinct. This potentially explained 'coincidences' like the surprising geographical correlation of confessional tradition with the 2004 enlargement.

EUS political scientists however largely left these complex Weberian analyses to specialists in history and culture. They instead treated culture and history as present legacies, in order to correlate them with immediately politically relevant factors like democracy. Some of this work only barely recognised history and culture. Gerda Falkner and Oliver Trieb’s definition of 
'culture' as a 'shared interpretive scheme' or 'set of cognitive rules and recipes' was very specifically synchronic for example (2008, 296-97). The political scientist David Laitin meanwhile limited his working definition of culture to aesthetic tastes, religion and language, and emphasised that these could change across generations (2002, 65). Rose and Haerpfer's 1995 analysis of opinion poll data on political values in candidate states and Falkner and Trieb's 2008 work on compliance of states with EU laws both examined the differentiated geography of entrenched institutions, which for historical sociology were eminently cultural. However both papers were presented in rationalist socio-political terms, did not reference culture, and historical elements were absent.

Studies of how the accession countries' diversity would affect the EU's functioning offer a key example of this crypto-cultural rationalism. Central to this debate was the 'match or missmatch' theory of German political scientist Adrienne Héritier, who argued that Europeanisation depended heavily on 'compatibility between national and European policies and institutions (Börzel and Heinze, 2012, 230 \& 236). Falkner and Treib in Vienna thus identified different 'worlds of compliance' with EU legislation, discovering that some new member states were in the least compliant of their four 'worlds', though they shared this distinction with some older member states (see fig. 3).

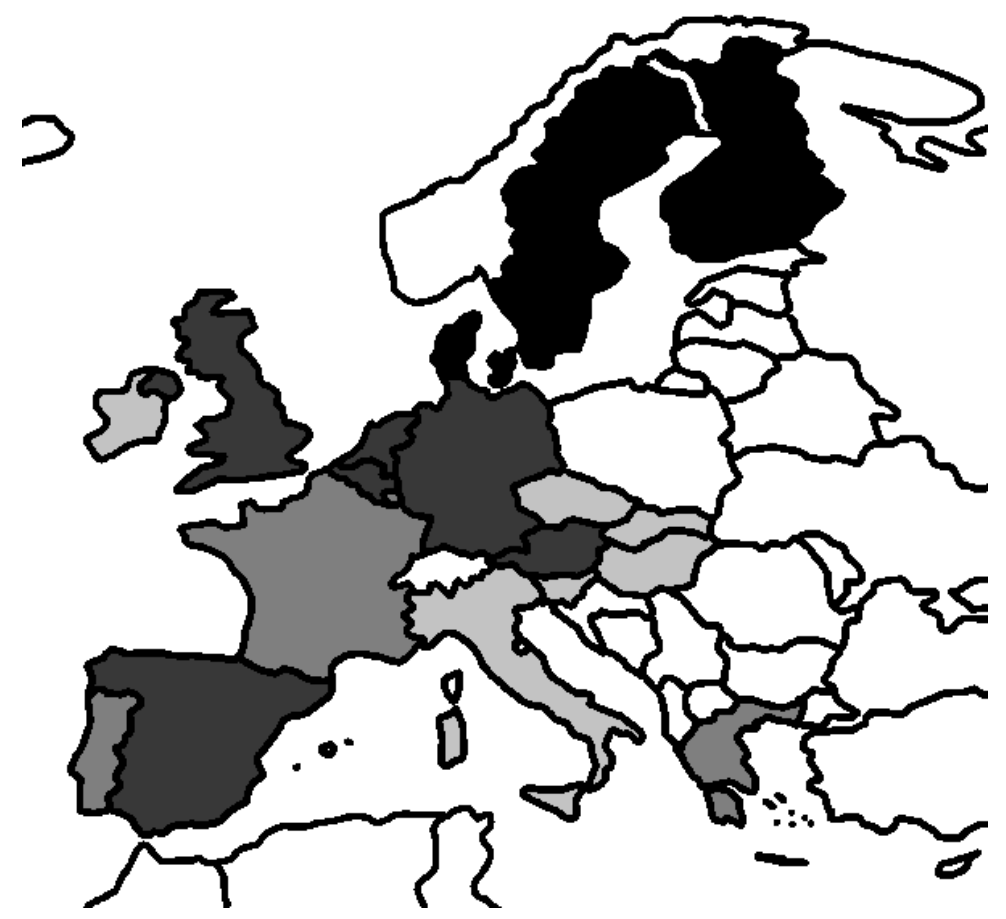

Fig. 3. Falkner and Treib's four 'worlds of compliance' (2008). Numbers run from darkest to palest

1. Law observance: compliance 'typically overrides domestic concerns'.

2. Domestic politics: cost/benefit debates in domestic politics can delay transposition.

3. Transposition neglect: typically ignores the duty to transpose.

4. Dead letters: transposition occurs but the measures are poorly enforced.

\section{Conclusion}

Though EUS emphasises rationalist explanations, often based on concrete economic or security interests, its analyses of EU enlargement are often not simply 'scientific' and value-free. Choice of research question and data, analytical tools, interpretation and presentation all provide (sometimes unconscious) opportunities for normativity, including normative interpretations of culture. A minority of EUS scholars actively employ concepts of civilisation or, less controversially, culture. Much constructivist scholarship dedicated itself to deconstructing normative use of cultural norms, narratives and discourses, such as the 
kidnapped West or Christian Europe. Rationalists by contrast tend not to problematise their own objectivity. This may make them less conscious of their fairly frequent use of civilisational ideas, including inadvertently in terminology such as Europe, West and East or in throwaway remarks in the introductions of scholarly articles.

Civilisations appear to be a key element in discourses about cultural influence on the spatial patterns of enlargement. This is no doubt partly because civilisational narratives about Europeanness have historically been strongly structured around an ideologically-infused eastwest continuum. For over a century, narratives of civilisation have excluded either the liberal west or the conservative east from Europe. Discourses of a post-modern Western European culture meanwhile exclude America, Russia and possibly even the 2004 EU accession states.

Civilisational logic quite possibly helped persuade Western European leaders to enlarge the EU to the east and is probably severely damaging Turkey's candidacy. If EU decision-makers paid as little attention to divisions within Christianity as leading EUS scholars apparently did, it is less probable that civilisation discourse impeded the accession of Orthodox countries. Most EU decision-makers probably knew or cared little about the potent civilisational discourses in many central European countries, which portrayed immediately neighbouring nations as Asiatic barbarians (Schimmelfennig 2001, 69). EU debates instead concentrated on whether to enlarge and how many countries to include. As long as candidates were Christian, the specific choice was left to technical criteria.

An alternative approach to culture, focusing on the different historically emerging practices, institutions and understandings of groups of people rather than on discourse and representations, is equally significant for understanding the evolution of the EU's geography. Historical sociology and also of a great deal of sociologically-inclined comparative rationalist work in EUS, for example on Europeanisation, public opinion or party politics, studies these socio-political differences. Only a minority of this research foregrounds the culture concept, but if it did so, it could potentially make a very useful contribution to complexifying the category of civilisation. The civilisations of conservative politicians and writers like Huntington simplify the historical geography of culture. They are sharply delineated groupings, approximating to mega-nations and usually based on one single characteristic, such as religious tradition. This reduces enlargement issues to a simple, immutable binary of culturally European or non-European.

By recognising multiple interacting historical experiences, each with its own geography, historical sociology can recognise cultural effects on politics in a more sophisticated and appropriate way. This is particularly suited to studying the EU's complex, gradual and differentiated eastward extension of relations with formerly communist countries. Crucially, this approach also identifies elements of both change and continuity in cultural geography, rather than treating it in essential terms. It could reveal Europe's correlation of confessional and enlargement geographies as a mere coincidence for example, or theoretically bolster the civilisation concept by demonstrating that historical geographies of culture can reinforce themselves over time.

Enlargement is meanwhile just part of a much broader differentiation of the EU's geography, which includes different memberships in schemes like the Euro and Schengen, opt-outs, the fuzzy borders created by association agreements, rates of Europeanisation and, of course, the partial dis-integration involved in Brexit. Research involving history, geography and culture can help make sense of all of these. 


\section{Bibliography}

- Adler, Emanuel. 2010, “Europe as a civilizational community of practice.” In Civilizations in World Politics: Plural and Pluralist Perspectives, edited by Peter Katzenstein, 67-90. New York: Routledge.

- Agnew, John. 2001. "How many Europes? The European Union, eastward enlargement and uneven development”. European Urban and Regional Studies 8(1): 29-38.

- Baldwin, Richard E. 1995. “The eastern enlargement of the European Union”. European Economic Review 39(3): 474-481.

- Baldwin, Richard E, J.F. Francois, and R. Portes. 1997. "The costs and benefits of eastern enlargement: the impact on the EU and central Europe". Economic policy 12(24): 125-176.

- Bassin, Mark, and Konstantin E. Aksenov. 2006, "Mackinder and the Heartland Theory in Post-Soviet Geopolitical Discourse.” Geopolitics 11(1): 99-118.

- Belot, Céline, and Claire Brachet. 2004. "Note de synthèse." Politique européenne 3: 149-163.

- Berling, Trine Villumsen, and Christian Bueger. 2013. "Practical reflexivity and political science: Strategies for relating scholarship and political practice.” PS: Political Science \& Politics 46(1): 115-119

- Börzel, Tanja, and Torben Heinze. 2012, "German EU Studies Oder EU Studies in Germany?” In Analyzing European Union Politics, edited by Federiga Bindi and Kjell A. Eliassen, 219-69, Bologna: Il Mulino.

- Braghiroli, Stefano, and Andrey Makarychev. 2016. "Russia and its supporters in Europe: trans-ideology à la carte?” Southeast European and Black Sea Studies 16(1): $1-21$.

- Christiansen, Thomas, Fabio Petito, and Ben Tonra. 2000. "Fuzzy Politics around Fuzzy Borders: The European Union's Near Abroad.” Cooperation and conflict 35(4): 389-415.

- Cichowski, Rachel A.. 2000. "Western dreams, Eastern realities: support for the European Union in Central and Eastern Europe.” Comparative Political Studies 33(10): 1243-1278.

- Delanty, Gerard. 1995. Inventing Europe: idea, identity, reality. London: Palgrave Macmillan.

- Diez, Thomas. 2004, "Europe's others and the return of geopolitics." Cambridge Review of International Affairs 17(2): 319-335.

- Falkner, Gerda, and Oliver Treib. 2008. "Three Worlds of Compliance or Four? The EU-15 Compared to New Member States.” JCMS: Journal of Common Market Studies 46(2): 293-313.

- Fierke, Karin M., and Antje Wiener. 2005. “Constructing Institutional Interests: EU and NATO enlargement.” In The politics of European Union enlargement: theoretical approaches, edited by Frank Schimmelfennig and Ulrich Sedelmeier, 99-119. Abingdon: Routledge.

- Friis, Lykke, and Anna Murphy. 1999. "The European Union and Central and Eastern Europe: Governance and boundaries.” JCMS: Journal of Common Market Studies 37(2): 211-232.

- Fuchs, Dieter, and Hans-Dieter Klingemann. 2002. "Eastward enlargement of the European Union and the identity of Europe.” In The Enlarged European Union: 
diversity and adaptation, edited by Peter Mair and Jan Zielonka, 19-54. London: Frank Cass.

- Gehler, Michael. 2006. "From Paneurope to the Single Currency: Recent Studies on the History of European Integration.” Contemporary European History 15(2): 273-289.

- Georgakakis, Didier, and Andy Smith. 2004. "Enseigner l'Europe." Politique européenne 3: 5-19.

- Gilbert, Mark. 2008. "Narrating the Process: Questioning the Progressive Story of European Integration.” Journal of Common Market Studies 46(3): 641-662.

- Grabbe, Heather, and Kirsty Hughes. 1998. Enlarging the EU Eastward. London: Pinter.

- Grabbe, Heather, and Ulrich Sedelmeier. 2010. “The future shape of the European Union.” In Research Agendas in EU Studies: Stalking the Elephant, edited by Michelle Egan, Neill Nugent and William E. Paterson, 375-97. Houndmills, Basingstoke: Palgrave Macmillan.

- Harzing, Anne-Wil K., and Ron Van der Wal. 2008. "Google Scholar as a New Source for Citation Analysis.” Ethics in Science and Environmental Politics 8: 61-73. doi: 10.3354/esep00076.

- Huntington, Samuel. 1993. “The clash of civilizations?” Foreign Affairs 72(3): 22-49.

- Huntington, Samuel. 1998. The Clash of Civilizations and the Remaking of World Order. London: Touchstone.

- Judt, Tony. 1992. "Ex Oriente Lux? Post-Celebratory Speculations.” In Towards Greater Europe? a continent without an iron curtain, edited by Colin Crouch and David Marquand, 91-104. Oxford: Blackwell.

- Judt, Tony. 1996, A Grand Illusion?: an essay on Europe. New York: NYU Press.

- Katzenstein, Peter J. 2005. A World of Regions: Asia and Europe in the American Imperium. Ithica: Cornell University Press.

- Katzenstein, Peter J. 2010. "A World of Plural and Pluralist Civilizations: Multiple Actors, Traditions and Disciplines”. In Civilizations in World Politics. Plural and Pluralist Perspectives, edited by Peter J. Katzenstein, 1-39, Abingdon: Routledge.

- Katzenstein, Peter J., and T.A. Byrnes. 2006. "Transnational religion in an expanding Europe.” Perspectives on Politics 4(4): 679-694.

- Kopecký, Petr, and Cas Mudde. 2002. "The Two Sides of Euroscepticism: Party positions on European integration in East Central Europe.” European Union Politics 3(3): 297-326.

- Kramer, Heinz. 1993. “The European Community's Response to the 'New Eastern Europe’.” JCMS: Journal of Common Market Studies 31(2): 213-244.

- Kundera, Milan. 1983. "Un Occident kidnappé. ou la tragédie de l'Europe centrale.” Le Débat 5(27): 3-23.

- Laitin, David D. 2002. "Cultural and National Identity: “The East” and European Integration”. In The enlarged European Union: diversity and adaptation, edited by Peter Mair and Jan Zielonka, 55-80. London: Frank Cass.

- Larat, Fabrice. 2006. "L'Europe à la recherche d'une figure tutélaire.” Politique européenne 18(1): 49-67.

- Lavenex, Sandra. 2004. “EU External Governance in 'Wider Europe'.” Journal of European Public Policy 11(4): 680-700.

- Lavenex, Sandra. 2011. “Concentric Circles of Flexible 'EUropean’ Integration: A typology of EU external governance relations.” Comparative European Politics 9(4): 372-393. 
- Mackinder, Halford John. 1904. The Geographical Pivot of History. London: Royal Geographical Society.

- Marks, Gary, Liesbet Hooghe, Moira Nelson, and Erica Edwards. 2006. Party Competition and European Integration in the East and West: Different structure, same causality.” Comparative Political Studies 39(2): 155-175.

- Moravcsik, Andrew, and Milada Vachudova. 2002. "National Interests, State Power, and EU Enlargement.” Perspectives 19: 21-31.

- Moravcsik, Andrew, and Milada Vachudova. 2005. "Preferences, power and equilibrium: the causes and consequences of EU enlargement.” In The politics of European Union enlargement: theoretical approaches, edited by Frank Schimmelfennig and Ulrich Sedelmeier, 198-212. London: Routledge.

- Neumann, Iver B. 1999. Uses of the other:" the East" in European identity formation. Manchester: Manchester University Press.

- Orluc, Katiana. 2000. "Decline or Renaissance: The Transformation of European Consciousness after The First World War." In Europe and the other and Europe as the other, edited by Bo Stråth, 123-55, Brussels: P.I.E.-P. Lang.

- Popa, Ioana. 2007. "La structuration internationale des études européennes: un espace scientifique dissymétrique." In La "nouvelle gouvernance européenne". Genèses et usages politiques d'un livre blanc, edited by Didier Georgakakis and de Lassalle Marine, 117-148. Strasbourg: Presses Universitaires de Strasbourg

- Risse, Thomas. 2006. "Social constructivism and European integration." In European Integration Theory, edited by Antje Wiener and Thomas Diez, 144-60. Oxford: Oxford University Press.

- Risse, Thomas. 2010, A Community of Europeans? Transnational identities and public spheres. Ithica: Cornell University Press.

- Rosamond, Ben. 2007. "The political sciences of European integration: disciplinary history and EU studies.” In The SAGE Handbook of European Union Politics, edited by Knud Erik Jorgensen, Mark Pollack, and Ben J Rosamond, 7-30. London: Sage.

- Rose, Richard, and Christian Haerpfer. 1995. "Democracy and Enlarging the European Union Eastwards.” JCMS: Journal of Common Market Studies 33(3): 427-450.

- Sanderson, Stephen K. 1995. "Civilisational Approached to World-Historical Change.” In Civilisations and World Systems: Studying World-Historical Change, edited by Stephen K. Sanderson, 15-23, Walnut Creek: Alta Mira Press.

- Schimmelfennig, Frank. 2001. "The community trap: Liberal norms, rhetorical action, and the Eastern enlargement of the European Union", International Organization 55(1): 47-80

- Schimmelfennig, Frank. 2003. "Strategic Action in a Community Environment: The Decision to Enlarge the European Union to the East." Comparative Political Studies 36(1-2): 156-183.

- Schimmelfennig, Frank, Stefan Engert, and Heiko Knobel. 2003. "Costs, commitment and compliance: the impact of EU democratic conditionality on Latvia, Slovakia and Turkey.” JCMS: Journal of Common Market Studies 41(3): 495-518.

- Schimmelfennig, Frank, and Hanno Scholtz. 2010. "Legacies and leverage: EU political conditionality and democracy promotion in historical perspective." EuropeAsia Studies 62(3): 443-460.

- Schimmelfennig, Frank, and Ulrich Sedelmeier. 2002. "Theorizing EU Enlargement: Research focus, hypotheses, and the state of research.” Journal of European Public Policy 9(4): 500-28. 
- Schimmelfennig, Frank, and Ulrich Sedelmeier. 2004. "Governance by conditionality: EU rule transfer to the candidate countries of Central and Eastern Europe." Journal of European Public Policy 11(4): 661-679.

- Sedelmeier, Ulrich. 2001. “Accommodation beyond self-interest: identity, policy paradigms, and the limits of a rationalist approach to EU policy towards central Europe.” Politique européenne 2: 13-34.

- Sjursen, Helene. 2002. "Why Expand? The Question of Legitimacy and Justification in the EU's Enlargement Policy.” Journal of Common Market Studies 40(3): 491-513.

- Sjursen, Helene. 2006. "Introduction: Enlargement and the nature of the EU polity." In Questioning EU Enlargement: Europe in search of identity, edited by Helene Sjursen, 1-15. London: Routledge.

- Smith, Anthony D. 1992. "National Identity and the Idea of European Unity." International Affairs, 68(1): 55-76.

- Smith, K.E. 2005. “The Outsiders: The European neighbourhood policy.” International Affairs 81(4): 757-773.

- Stawarska, Renata. 1999. "EU enlargement from the Polish perspective.” Journal of European Public Policy 6(5): 822-838.

- Szúcs, Jenó. 1985. Les trois Europes. Paris: L'Harmattan.

- Taggart, Paul, and Aleks Szczerbiak. 2004. "Contemporary Euroscepticism in the party systems of the European Union candidate states of Central and Eastern Europe.” European Journal of Political Research 43(1): 1-27.

- Therborn, Göran. 1995. European modernity and beyond: the trajectory of European societies, 1945-2000. London: Sage.

- Wallace, Helen. 2005. "Enlarging the European Union: reflecting on the challenge of analysis." In The politics of European Union enlargement: theoretical approaches, edited by Frank Schimmelfennig, and Ulrich Sedelmeier, 287-94. Abingdon: Routledge.

- Wallace, William. 1992. "From Twelve to Twenty-Four? The Challenges to the EC Posed by the Revolutions in Eastern Europe.” In Towards Greater Europe? A Continent without an Iron Curtain, edited by Colin Crouch, and David Marquand, 3451. Oxford: Blackwell Publishers.

- Wallerstein, Immanuel. 1974. "The Rise and Future Demise of the World Capitalist System: Concepts for comparative analysis.” Comparative studies in society and history 16(4): 387-415.

- Weiss, Gilbert. 2002. “A.E.I.O.U. - Austria Europae Imago, Onus, Unio?” In The Meaning of Europe, edited by Mikael af Malmborg and Bo Stråth, 263-85. Oxford: Berg.

- Wessels, Wolfgang. 1993. "Erweiterung, Vertiefung, Verkleinerung. Vitale Fragen für die Europäische Union.” Europa-Archiv 48(8): 308-316.

- Wolff, Larry. 1994. Inventing Eastern Europe: The map of civilization on the mind of the enlightenment. Stanford: Stanford University Press.

- Zielonka, Jan. 1998. Explaining Euro-Paralysis. Why Europe is Unable to Act in International Politics. London: Macmillan.

- Zielonka, Jan. 2001. "How new enlarged borders will reshape the European Union." JCMS: Journal of Common Market Studies 39(3): 507-536.

- Zielonka, Jan, and Peter Mair. 2002. "Introduction: diversity and adaptation in the enlarged European Union.” In The enlarged European Union: diversity and adaptation, edited by Peter Mair and Jan Zielonka, 1-18. London: Frank Cass. 